\title{
CORRECTION
}

\section{Correction to: Effect of protocol on peak power output in continuous incremental cycle exercise tests}

\author{
Hans Luttikholt ${ }^{1}\left[\right.$ ] Andrew M. Jones ${ }^{2}$
}

Published online: 9 February 2022

○) Springer-Verlag GmbH Germany, part of Springer Nature 2022

Correction to: European Journal of Applied Physiology https://doi.org/10.1007/s00421-021-04880-5

The original version of this article unfortunately contained a mistake. The value of 0.001752 for calibration factor $A$ in Eq. 2 is incorrect. The correct factor should be 0.00054196 .

Publisher's Note Springer Nature remains neutral with regard to jurisdictional claims in published maps and institutional affiliations.

The original article can be found online at https://doi.org/10.1007/ s00421-021-04880-5.

Hans Luttikholt

hansluttikholt@caiway.nl

1 Sport Research, 7004HH Doetinchem, The Netherlands

2 University of Exeter, Sport and Health Sciences,

Exeter EX12LU, UK 